\title{
SURFACE MORPHOLOGY ANALYSIS OF X39Cr13 STEEL USING FOR BIOMEDICAL APPLICATIONS
}

\author{
${ }^{1}$ Monika GWOŹDZIK, ${ }^{2}$ Sławomir KULESZA, ${ }^{3}$ Mirosław BRAMOWICZ \\ ${ }^{1}$ Czestochowa University of Technology, Faculty of Production Engineering and Materials Technology, \\ Institute of Materials Engineering, Czestochowa, Poland, EU, gwozdzik.monika@wip.pcz.pl \\ 2University of Warmia and Mazury in Olsztyn, Faculty of Mathematics and Computer Science, Olsztyn, \\ Poland,EU, slawek.kulesza@matman.uwm.edu.pl \\ ${ }^{3}$ University of Warmia and Mazury in Olsztyn, Faculty of Technical Sciences, Olsztyn, Poland, EU, \\ miroslaw.bramowicz@uwm.edu.pl
}

https://doi.org/10.37904/metal.2019.873

\begin{abstract}
The presented paper contains the results of research on fractal analysis. The fractal analysis was carried out on $\mathrm{X} 39 \mathrm{Cr} 13$ steel subjected to heat, surface and thermo-chemical treatments. The research was carried out according to various variants: hardening + tempering $(H / T)$, hardening + tempering + surface treatment $(H / T / N$, hardening + tempering + surface treatment + sterilization $(\mathrm{H} / \mathrm{T} / \mathrm{N} / \mathrm{S})$, hardening + tempering + sterilization + corrosion resistance test $(\mathrm{H} / \mathrm{T} / \mathrm{S} / \mathrm{C}$, hardening + tempering + surface treatment + sterilization + corrosion resistance test $(\mathrm{H} / \mathrm{T} / \mathrm{N} / \mathrm{S} / \mathrm{C})$. Spatial characteristics of the surface texture of steel samples were derived from SEM images.
\end{abstract}

Keywords: X39Cr13 steel, fractal analysis, surface topography

\section{INTRODUCTION}

On the world the strives to improve the properties of materials by applying different types of coatings to materials. More and more research centers conduct research related to the modification of the surface layer of materials [1-16]. This is due to the fact that conventional materials do not always meet specific requirements, for example the effect of combining wear and corrosion resistance, which can significantly accelerate the material degradation process. In paper [1], the authors developed antibacterial coatings based on the S phase. The researchers applied magnetron deposition by co-deposition of austenitic stainless steel with $\mathrm{Ag} / \mathrm{Cu}$ to form a hard S-phase doped with $\mathrm{Ag}$, Cu or both in monolayer and multilayer structures. The researches have been shown that, it is possible to produce dense Ag and Cu doped S-phase layer with significant anti-bacterial efficacy. In paper [3] the metals were subjected to surface modifications by plasma nitriding or physical vapor deposition to produce diamond-like carbon coating, respectively. On the other hand, in the paper [4], tests were carried out on $316 \mathrm{~L}$ stainless steel material subjected to plasma nitriding. Authors in the paper [4] stated that the temperature of treatment is the main factor influencing the properties of the layer produced on austenitic steel $316 \mathrm{~L}$. The studies related to the application of scanning electron microscopy (SEM) [1,17-27] and atomic force microscopy (AFM) $[19,23,28,29]$ are of great importance especially in material engineering. In this paper was used to extract non-random patterns from data series regardless of their origin: SEM images, and it was interpreted obtained characteristics in a consistent manner.

\section{MATERIALS AND EXPERIMENTAL METHODS}

Martensitic steel belonging to the group of stainless steel X39Cr13 according to EN 10088-1 [30] was selected for laboratory tests. The tests were carried out on samples with a thickness of $1 \mathrm{~mm}$. The tests were carried out on samples which were subjected to heat treatment consisting in hardening them with a $1050{ }^{\circ} \mathrm{C}$ austenitizing temperature. The holding time at this temperature was 20 minutes. After hardening, the steel was 
subjected to a two hour temper at $620^{\circ} \mathrm{C}$. Austenitization and tempering were carried out in a vacuum oven with compressed nitrogen cooling. Next, the plasma nitriding process was carried out. The sterilization process and the corrosion resistance tests were carried out for some of the samples. The nitriding was carried out at $T=460{ }^{\circ} \mathrm{C}$ and pressure $p=145 \mathrm{~Pa}$ during $t=20 \mathrm{~h} .25 \% \mathrm{~N}_{2}+75 \% \mathrm{H}_{2}$ was used as reactive atmosphere. The sterilization by steam was carried out in an autoclave at $T=134{ }^{\circ} \mathrm{C}$ and pressure $p=0.21 \mathrm{MPa}$ during time $t=0.5 \mathrm{~h}$ in for cycles. Corrosion resistance tests were performed in Tyrode's physiological solution $(p H=6.8 \div 7.4)$. Characteristics of multiscale patterns in surface topography of steel samples subjected to thermochemical processing were derived from their SEM images $[17,26]$. To this end, the numerical routine was carried out that begun with calculations of the 2-dimensional autocorrelation function $R$ :

$\mathrm{R}_{\mathrm{mn}}=\frac{1}{2 \mathrm{~S}_{\mathrm{q}}^{2}} \sum_{\mathrm{k}=1}^{\mathrm{N}-\mathrm{n}} \sum_{\mathrm{l}=1}^{\mathrm{M}-\mathrm{m}}(\mathrm{z}(\mathrm{x}+\mathrm{m}, \mathrm{y}+\mathrm{n}) \cdot \mathrm{z}(\mathrm{x}, \mathrm{y}))$

where:

$m, n$ - discrete translation of a duplicated image from the origin

$S_{q}$ - root-mean-square surface roughness

$N, M$ - the numbers of scan steps along each side.

Axial differences surface geometry can be expressed using anisotropy ratio $S_{t r}$, defined as the proportion of two extreme decay lengths of lateral autocorrelation [31]:

$\mathrm{S}_{\mathrm{tr}}=\frac{\mathrm{L}_{\mathrm{a} 1}}{\mathrm{~L}_{\mathrm{a} 2}}$

where:

$L_{a 1}$, and $L_{a 2}$ - are the smallest and largest decay lengths, respectively

In the next step, 2-dimensional autocorrelation function was averaged around its origin into 1-dimensional autocorrelation curve $R(T)$, and then processed to obtain the structure function $S(T)$ according to the formula [31]:

$S(\tau)=2 S_{q}^{2}(1-R(\tau))$

Sayles and coworkers demonstrated that the structure function is governed by specific scaling law [32]:

$S(\tau)=K \tau^{2(2-D)}$

where:

$$
\begin{aligned}
& D \text { - is the fractal dimension } \\
& K \text { - pseudo-topothesy }
\end{aligned}
$$

As a rule, $D$ and $K$ correspond to the way, how the relative and absolute height variations remain scaleinvariant, respectively. However, the allometric scaling remains valid as long as the scale size does not exceed certain threshold level, referred to as the corner frequency ( $\tau_{a 1}, T_{a 2}$ depending on the direction), beyond which the plot turns flat. On the other hand, in case of materials with hierarchical structure of surface patterns, multiple scaling regimes are supposed to occur independent of each other. 


\section{RESULTS OF EXAMINATION}

SEM images shown in Figures 1(a-e) present grayscale surface maps of steel samples taken from rectangular areas 25 by $35 \mu \mathrm{m}$ in size. The images reveal changes brought about by consecutive processing steps of the thermochemical treatment, that is: hardening and tempering $(H / T)$, nitriding $(H / T / N)$, sterilization $(H / T / N / S)$ and corrosion tests $(H / T / S / C$ and $H / T / N / S / C)$. Example log-log plot of a profile structure function demonstrating this behavior is shown in Figure 1f.
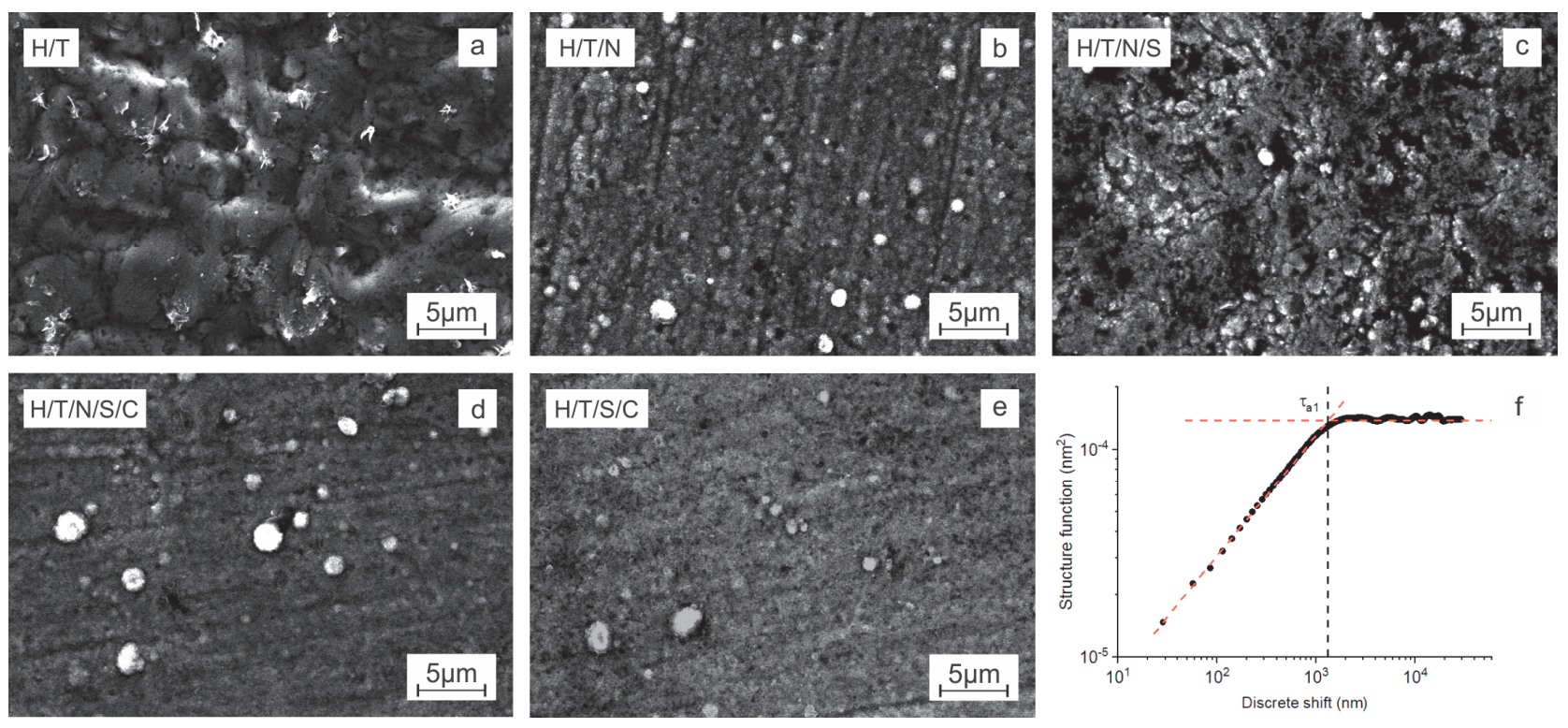

Figure 1 SEM images of $\mathrm{X} 13 \mathrm{Cr} 39$ steel samples at various stages of thermochemical treatment procedure:

(a) hardening and tempering, (b) nitriding, (c) sterilization, (d) corrosion test after nitriding followed by sterilization, (e) corrosion test after sterilization. Apart from that, (f) shows example log-log plot of the profile structure function in the direction of fast correlation decay determined from SEM image of the hardened and tempered sample.

Surface of the steel specimen seen in Figure 1(a) is found rough with tiny although very sharp needle-like precipitates that shine bright under electron illumination. Based on their lower work function the precipitates may be linked to $\mathrm{M}_{23} \mathrm{C}_{6}$ carbides. Figure 1(b) presents SEM image of the same sample after being nitrided. Unlike hardening, however, the nitriding ends up in a surface texture dominated by regular grains around $1 \mu \mathrm{m}$ in diameter spread randomly on otherwise flat surface with thin and shallow ridges. Various foreign compounds, mostly $\mathrm{Fe}_{2} \mathrm{~N}$ and $\mathrm{CrN}$, are found to diffuse deep inside the material during nitriding, which leads to formation of the nitride layer. Figure 1(c) shows the surface of previously nitrided sample subjected in the following to sterilization. Similar to the nitrided sample, numerous grains around $1 \mu \mathrm{m}$ in size can be spotted in the image, however the surface itself no longer exhibits any ridges. Instead, well-separated dimples can be seen. Samples subjected to corrosion tests in Tyrode's solution shows in Figures 1(d) and Figures 1(e) do not differ significantly in their geometrical appearance regardless of the details of preceding treatments. Both images exhibit the presence of large, regular grains 2-3 $\mu \mathrm{m}$ wide lying on flat surface with no other distinct features. Table 1 presents statistical and angle-dependent characteristics of the surface geometry of investigated samples determined for both directions of spatial decays of horizontal autocorrelation. In general, anisotropy ratio is found to increase steadily after each step of the treatment procedure from fairly low value 0.57 specific of moderately isotropic structures to 0.92 corresponding to highly isotropic surfaces. Apart from that, all samples exhibit monofractal characteristics mostly affected by the presence of spherical grains in SEM images. On one hand, obtained fractal dimensions are found to lie in the narrow range between 1.6 and 1.8 specific of well-developed surfaces, that is surfaces with significant magnitude of height variations at different length scales. On the other hand, however, allometric scaling behavior disappears independent of the line of 
observation shortly after the shift in lateral correlation achieves the limit of few hundreds nanometers established by the corner frequency. Here, corner frequency agrees well with the size of spherical grains seen in SEM images, and such a result suggests that geometrical structures stay in close relation to scale-invariant measures. From the above observations the conclusion can be drawn that no aggregation process occurs on the surface of the steel samples subjected to various treatment procedures, which agrees with predominant topographical features seen in SEM images.

Table 1 Axial characteristics of surface texture geometry of steel samples: $S_{t r}$ - anisotropy ratio, $D$ - fractal dimension, $T$ - corner frequency, $a_{1}$ - fast-decay axis, $a_{2}$ - slow-decay axis

\begin{tabular}{|c|c|c|c|c|c|}
\hline \multirow[b]{2}{*}{ Sample } & \multirow[b]{2}{*}{$S_{t r}$} & \multicolumn{2}{|c|}{$a_{1}$ axis } & \multicolumn{2}{|c|}{$a_{2}$ axis } \\
\hline & & $\mathbf{D}_{1}$ & $\begin{array}{c}\tau_{1} \\
(\mathrm{~nm})\end{array}$ & $\mathbf{D}_{1}$ & $\begin{array}{c}\tau_{1} \\
(\mathrm{~nm})\end{array}$ \\
\hline $\mathrm{H} / \mathrm{T}$ & 0.57 & 1.71 & 1320 & 1.71 & 1600 \\
\hline $\mathrm{H} / \mathrm{T} / \mathrm{N}$ & 0.75 & 1.71 & 600 & 1.79 & 950 \\
\hline $\mathrm{H} / \mathrm{T} / \mathrm{N} / \mathrm{S}$ & 0.91 & 1.61 & 560 & 1.66 & 670 \\
\hline $\mathrm{H} / \mathrm{T} / \mathrm{N} / \mathrm{S} / \mathrm{C}$ & 0.92 & 1.72 & 1100 & 1.72 & 1200 \\
\hline $\mathrm{H} / \mathrm{T} / \mathrm{S} / \mathrm{C}$ & 0.81 & 1.81 & 820 & 1.62 & 870 \\
\hline
\end{tabular}

\section{CONCLUSION}

The fractal analysis was performed on samples of $\mathrm{X} 39 \mathrm{Cr} 13$ steel. The obtained results are as follows:

- $\quad$ after the nitriding process on the surface of the tested samples, regular grains with a diameter of about $1 \mu \mathrm{m}$ were distributed unevenly distributed on a flat surface with thin and shallow ridges. However, after sterilization of nitrided samples, only $1 \mu \mathrm{m}$ grains were observed without characteristic ridges,

- $\quad$ after corrosion tests no significant changes in the steel tested were observed,

- $\quad$ the ratio of anisotropy in the test samples increases after each processing step from $0.57(\mathrm{H} / \mathrm{T})$ to 0.92 $(\mathrm{H} / \mathrm{T} / \mathrm{N} / \mathrm{S} / \mathrm{C})$.

\section{REFERENCES}

[1] FORMOSA, Dennis, LI, Xiaoying, SAMMONS, Rachel and DONG, Hanshan. Development and characterisation of novel anti-bacterial S-phase based coatings. Thin Solid Films. 2017. vol. 644, pp. 71-81.

[2] STIO, Maria, MARTINESI, Maria, TREVES, Cristina and BORGIOLI, Francesca. Cultures and co-cultures of human blood mononuclear cells and endothelial cells for the biocompatibility assessment of surface modified AISI 316L austenitic stainless steel. Materials Science \& Engineering C-Materials for Biological Applications. 2016. vol. 69, pp. 1081-1091.

[3] ZHAO, Guo-Hua, AUNE, Ragnhild and ESPALLARGAS, Nuria. Tribocorrosion studies of metallic biomaterials: The effect of plasma nitriding and DLC surface modifications. Journal of the Mechanical Behavior of Biomedical Materials. 2016. vol. 63, pp. 100-114.

[4] YETIM, Ali Fatih and YAZICI, Mustafa. Wear Resistance and Non-Magnetic Layer Formation on 316L Implant Material with Plasma Nitriding. Journal of Bionic Engineering. 2014. vol. 11, no. 4, pp. 620-629.

[5] BUHAGIAR, Joseph and DONG, Hanshan. Corrosion properties of S-phase layers formed on medical grade austenitic stainless steel. Journal of Materials Science-Materials in Medicine. 2012. vol. 23, no. 2, pp. 271-281.

[6] GWOŹDZIK, Monika and NITKIEWICZ, Zygmunt. Topography of X39Cr13 steel surface after heat and surface treatment. Optica Applicata. 2009. vol. 39, no. 4, pp. 853-857.

[7] GWOŹDZIK, Monika and NITKIEWICZ, Zygmunt. Wear resistance of steel designed for surgical instruments after heat and surface treatments. Archives of Metallurgy and Materials. 2009. vol. 54, no. 1, pp. 241-246. 
[8] JUNG, Anne, BUCHWALDER, Anja, HEGELMANN, Eugen, HENGST, Philipp and ZENKER, Rolf. Surface engineering of spray-formed aluminium-silicon alloys by plasma nitriding and subsequent electron beam remelting. Surface \& Coatings Technology. 2018. vol. 335, pp. 166-172.

[9] TANG, Lei, JIA, Weiju and HU, Jing. An enhanced rapid plasma nitriding by laser shock peening. Materials Letters. 2018. vol. 231, pp. 91-93.

[10] BOSE, Susmita, KE, Dongxu, SAHASRABUDHE, Himanshu and BANDYOPADHYAY, Amit. Additive manufacturing of biomaterials. Progress in Materials Science. 2018. vol. 93, pp. 45-111.

[11] PICHON, Luc, DUBOIS, Jean-Baptiste, CHOLLET, Sebastien, LAREK, Fadella, CORMIIER, Jonathan and TEMPLIER, Claude. Low temperature nitriding behaviour of Ni3Al-like gamma ' precipitates in nickel-based superalloys. Journal of Alloys and Compounds. 2019. vol. 771, pp. 176-186.

[12] BRACERAS, Inigo, IBANEZ, Inigo, DOMINGUEZ-MEISTER, Santiago, ANGEL SANCHEZ-GARCIA, Jose, BRIZUELA, Marta, LARRANAGA, Aitor and GARMENDIA, Inaki. Plasma nitriding of the inner surface of stainless steel tubes. Surface \& Coatings Technology. 2018. vol. 355, pp. 116-122.

[13] TAACA, Kathrina Lois M. and VASQUEZ, Magdaleno R. Hemocompatibility and cytocompatibility of pristine and plasma-treated silver-zeolite-chitosan composites. Applied Surface Science. 2018. vol. 432, pp. 324-331.

[14] KUMAR, Ranvijay, SINGH, Rupinder, HUI, David, FEO, Luciano and FRATERNALI, Fernando. Graphene as biomedical sensing element: State of art review and potential engineering applications. Composites Part B: Engineering. 2018. vol. 134, pp. 193-206.

[15] SHARMA, Gaurav, THAKUR, Bharti, NAUSHAD, Mu, KUMAR, Amit, STADLER, Florian J., ALFADUL, Sulaiman M. and MOLA, Genene Tessema. Applications of nanocomposite hydrogels for biomedical engineering and environmental protection. Environmental Chemistry Letters. 2018. vol. 16, no. 1, pp. 113-146.

[16] ZDRAVECKÁ, Eva, SLOTA, Jan, SOLFRONK, Pavel and KOLNEROVA, Michaela. Evaluation of the effect of different plasma-nitriding parameters on the properties of low-alloy steel. Journal of Materials Engineering and Performance. 2018. vol. 26, no. 7, pp. 5388-3596.

[17] GWOŹDZIK, Monika, BRAMOWICZ, Mirosław, KULESZA, Sławomir. Application of fractal geometry methods for analysis of X39Cr13 steel after heat and surface treatments. In METAL 2018: $27^{\text {th }}$ International Conference on Metallurgy and Materials. Ostrava: TANGER, 2018, pp. 1114-1120.

[18] LABISZ, Krzysztof, TAŃSKI, Tomasz, KREMZER, Marek and JANICKI, Damian. Effect of laser alloying on heattreated light alloys. International Journal of Materials Research. 2017. vol. 108, no. 2, pp. 126-132.

[19] LI, Yang, HE, Yongyong, XIU, JunJie, WANG, Wei, ZHU, YiJie and HU, Baoguo. Wear and corrosion properties of AISI 420 martensitic stainless steel treated by active screen plasma nitriding. Surface \& Coatings Technology. 2017. vol. 329, pp. 184-192.

[20] PENG, Jihua, ZHUA, Zhenzhong and SU, Dongyi. Sliding wear of nitrided and duplex coated H13 steel against aluminium alloy. Tribology International. 2019. vol. 129, pp. 232-238.

[21] DAMERCHI, Elyad, ABDOLLAH-ZADEH, Amir, POURSALEHI, Reza and MEHR, Mahtab Salari. Effects of functionally graded TiN layer and deposition temperature on the structure and surface properties of TiCN coating deposited on plasma nitrided H13 steel by PACVD method. Journal of Alloys and Compounds. 2019. vol. 772, pp. 612-624.

[22] KURELO, Bruna C.E.S., de OLIVEIRA, Willian R., SERBENA, Francisco C. and de SOUZA, Gelson B. Surface mechanics and wear resistance of supermartensitic stainless steel nitrided by plasma immersion ion implantation. Surface \& Coatings Technology. 2018. vol. 353, pp. 199-209.

[23] de OLIVEIRA, Willian R., KURELO, Bruna C. E. S., DITZEL, Dair G., SERBENA, Francisco C., FOERSTER, Carlos E. and de SOUZA, Gelson B. On the S-phase formation and the balanced plasma nitriding of austeniticferritic super duplex stainless steel. Applied Surface Science. 2018. vol. 434, pp. 1161-1174.

[24] LIN, Kaijie, LI, Xiaoying, DONG, Hanshan, GUO, Ping and GU, Dongdong. Nitrogen mass transfer and surface layer formation during the active screen plasma nitriding of austenitic stainless steels. Vacuum. 2018. vol. 148, pp. 224-229.

[25] LUO, Quanshun, OLUWAFEMI, Oluwaseun, KITCHEN, Matthew and YANG, Shicai. Tribological properties and wear mechanisms of DC pulse plasma nitrided austenitic stainless steel in dry reciprocating sliding tests. Wear. 2017. vol. 376-377, pp. 1640-1651. 
[26] KULESZA, Sławomir, BRAMOWICZ, Mirosław, GWOŹDZIK, Monika, WILCZYŃSKI, Sławomir, GOŹDZIEJEWSKA, Anna. Structural aging and degradation of human fingernail plates upon cosmetic agents. Archives of Metallurgy and Materials. 2019. vol. 64, no. 1, pp. 181-184.

[27] GWOŹDZIK, Monika. Analysis of crystallite size changes in an oxide layer formed on steel used in the power industry. Acta Physica Polonica A. 2016. vol. 130, no. 4, pp. 935-938.

[28] SAMANTA, Aniruddha, BHATTACHARYA, Manjima, RATHA, Itishree, CHAKRABORTY, Himel, DATTA, Susmit, GHOSH, Jiten, BYSAKH, Sandip, SREEMANY, Monjoy, RANE, Ramkrishna, JOSEPH, Alphonsa, MUKHERJEE, Subroto, KUNDU, Biswanath, DAS, Mitun and MUKHOPADHYAY, Anoop K. Nano- and micro-tribological behaviours of plasma nitrided Ti6Al4V alloys. Journal of the Mechanical Behavior of Biomedical Materials. 2018. vol. 77, pp. 267-294.

[29] GWOŹDZIK, Monika, KULESZA, Sławomir, BRAMOWICZ, Mirosław. Application of the fractal geometry methods for analysis of oxide layer. In METAL 2017: 26th International Conference on Metallurgy and Materials. Ostrava: TANGER, 2017, pp. 789-794.

[30] EN 10088-1: Stainless steels - Part 1: List of stainless steels.

[31] DONG, Weiping, SULLIVAN, Patrick, J., STOUT, Ken, J. Comprehensive study of parameters for characterising three-dimensional surface topography: IV: Parameters for characterising spatial and hybrid properties. Wear. 1994. vol. 178, pp. 45-60.

[32] SAYLES, Ritchie, S., Thomas T. R., Spatial representation of surface roughness by means of structure function practical alternative to correlation. Wear. 1977. vol. 42, pp. 263-276. 